\title{
CMA urges national action to curb third wave of COVID-19
}

\author{
Cite as: CMAJ 2021 May 3;193:E653-4. doi: 10.1503/cmaj.1095938
}

Posted on cmajnews.com on April 16, 2021

$\mathrm{T}$ he Canadian Medical Association (CMA) is calling for a national emergency response to the COVID-19 crisis unfolding in Ontario and other provinces.

"We are at a critical juncture where a true national approach to combatting COVID-19 will make the difference between more or less lives saved," said CMA President Dr. Ann Collins. "This country must come together to help support provinces most severely impacted."

On April 15, the number of new SARSCoV-2 infections in Canada surged past 9500 , setting a new single-day record. Nearly half of those cases came from Ontario, which reported a record 4736 new infections. The province recently predicted that number could escalate to more than 30000 a day by May.

More transmissible variants of the virus account for a large proportion of the new cases in several provinces and appear to be driving up hospitalizations. Ontario alone accounts for nearly 2000 of 3691 COVID-19 hospitalizations across Canada. According to provincial officials, the situation is becoming dire.

The CMA is calling for "extraordinary" measures to bring the crisis under control, including "marshalling national resources where needed, applying restrictive public health measures, and prioritizing national collaboration to save the most lives."

According to a statement, "this means sharing health care resources across provincial and territorial borders to help jurisdictions that are currently at crisis levels in ICUs and where health care capacity is overwhelmed." Better public health communication and enhanced paid sick leave are also "urgently required."

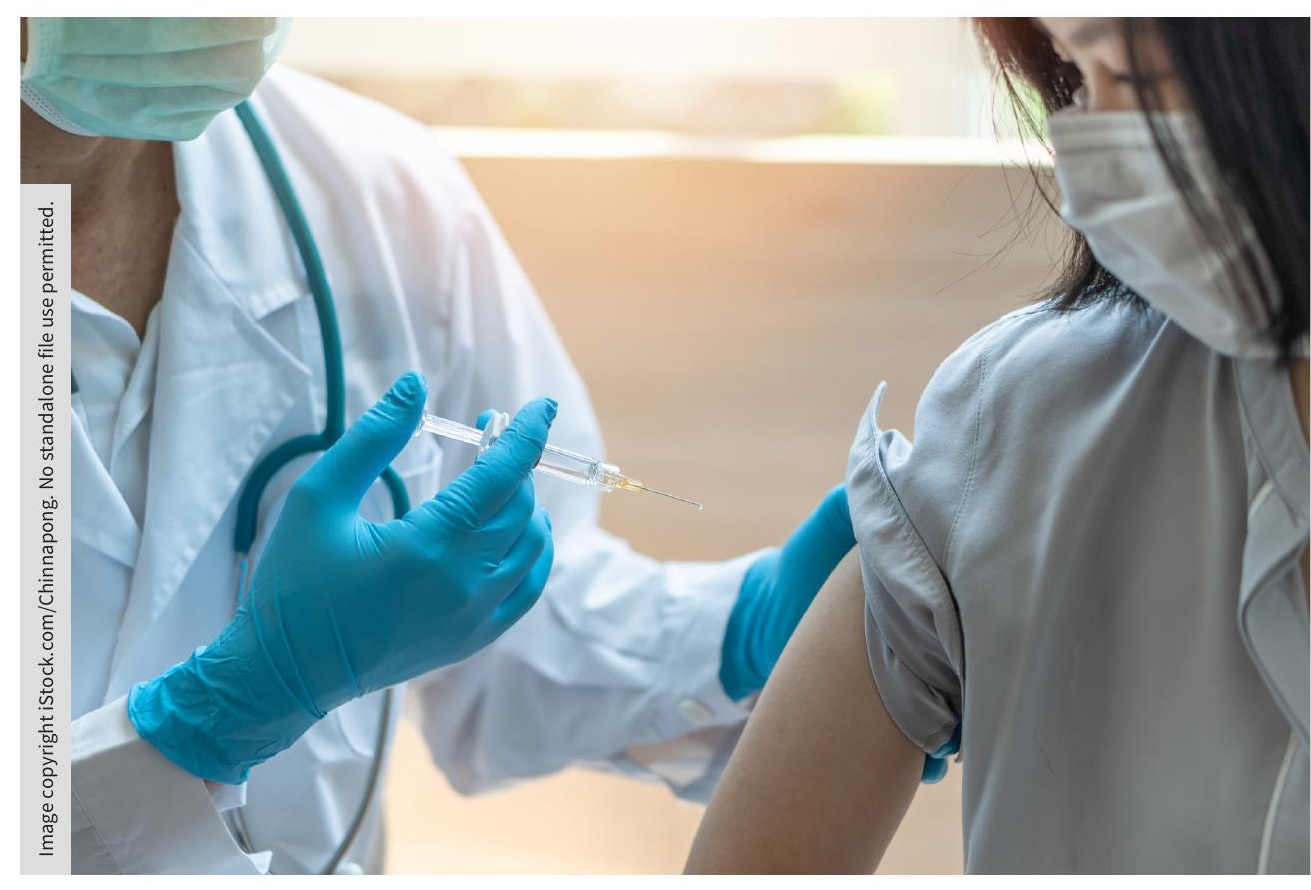

Healthcare resources including vaccines should be redeployed to provinces that need them most, according to the Canadian Medical Association.

"We act as one country when crisis hits with wildfires, floods and other tragedies," said Collins. "We must do everything needed to avoid making unbearable choices as to who lives if resources are not available."

The CMA is also urging the federal government to refocus vaccine distribution on the areas hit hardest by COVID19 , rather than divvying up doses between the provinces and territories based on population.

"If we can't achieve this through voluntary cooperation, then stronger measures might be needed," Collins said.

According to Prime Minister Justin Trudeau, any changes in the distribution of vaccines would have to be negotiated with the provinces. "We're happy to continue to work with the provinces on adjusting as the provinces see necessary," he said.

So far, few provinces seem keen to cooperate. Nova Scotia Premier lain Rankin dismissed the CMA's call for a redistribution of vaccines, arguing that "things can change very quickly."

"We've done the work, we've sacrificed and followed restrictions," he said. "There are still variants of concern across the country."

Ontario's government has reached out to every province and territory asking them to send nurses, respiratory therapists, perfusionists and anesthesia assistants to cover staffing shortfalls. 
The province is offering to pay health workers temporary relocation expenses and said length of stay would depend on Ontario's COVID-19 caseload and intensive care capacity.

While Newfoundland Premier Andrew Furey indicated that his province would be willing to pitch in, Alberta Premier Jason Kenney denied the request, stating "we are simply not in a position to send our health care workers."

Some health care workers have also expressed skepticism about the practi- cality of sharing human resources across Canada. According to Dr. Christopher Labos, a Montreal-based epidemiologist, "logistically, you can't move people around the country like pieces on a chessboard."

Meanwhile, Ontario has rejected an offer from the federal government to send mobile vaccination teams to Toronto and Hamilton without increasing the province's share of vaccines. According to Premier Doug Ford's office, when it comes to vaccination, "we do not have a capacity issue, we have a supply issue."

\section{Lauren Vogel, CMAJ}

Content licence: This is an Open Access article distributed in accordance with the terms of the Creative Commons Attribution (CC BY-NC-ND 4.0) licence, which permits use, distribution and reproduction in any medium, provided that the original publication is properly cited, the use is noncommercial (i.e., research or educational use), and no modifications or adaptations are made. See: https://creativecommons.org/ licenses/by-nc-nd/4.0/ 